\title{
PENGARUH CORPORATE SOCIAL RESPONSIBILITY DAN KUALITAS PELAYANAN TERHADAP LOYALITAS NASABAH MELALUI SIKAP NASABAH (Studi Pada Bank Muamalat KC. Malang)
}

\author{
Ach Rofiki \\ Universitas Trunojoyo Madura \\ achrofiki05071997@gmail.com \\ Nurhayati \\ Universitas Trunojoyo Madura \\ nur.hayati@trunojoyo.ac.id
}

\begin{abstract}
This study aims to analyze the effect of corporate social responsibility and service quality on customer loyalty with customer attitude as an intervening variable. The data source of this research is primary data from a sample of customers of Bank Muamalat KC. Poor. Data collection was carried out using purposive sampling by distributing to 100 respondents of Bank Muamalat KC customers. Malang that receives CSR assistance or who knows the implementation of CSR programs. Data analysis tool uses SmartPLS. The results of this study indicate that there is a direct influence of CSR on Customer Loyalty and Customer Quality on customer attitudes, and the indirect effect between service quality on customer loyalty through customer attitudes. While CSR has no effect on Customer Attitude and also Service Quality on Customer Loyalty, while Customer Quality has no indirect effect on customer loyalty through customer attitudes.
\end{abstract}

Keywords: Corporate social responsibility, service quality, customer attitudes, customer loyalty

\begin{abstract}
ABSTRAK
Penelitian ini bertujuan untuk menganalisis pengaruh corporate social responsibility dan kualitas pelayanan terhadap loyalitas nasabah dengan sikap nasabah sebagai variabel intervening. Sumber data penelitian ini merupakan data primer yang berasal dari sampel yaitu nasabah Bank Muamalat KC. Malang. Pengumpulan data dilakukan menggunakan purposive sampling dengan menyebarkan kepada 100 responden nasabah Bank Muamalat KC. Malang yang menerima bantuan CSR ataupun yang mengetahui implementasi program CSR. Alat analisis data menggunakan SmartPLS. Hasil penelitian ini menunjukkan bahwa adanya pengaruh langsung CSR terhadap Loyalitas Nasabah dan Kualitas Nasabah terhadap sikap nasabah, dan pengaruh tidak langsung antara kualitas pelayanan terhadap loyalitas nasabah melalui sikap nasabah. Sedangkan CSR tidak berpengaruh terhadap Sikap Nasabah dan juga Kualitas Pelayanan terhadap Loyalitas Nasabah, sedangkan Kualitas Nasabah tidak berpengaruh secara tidak langsung terhadap loyalitas nasabah melalui sikap nasabah.
\end{abstract}

Kata kunci : Corporate social responsibility, kualitas pelayanan, sikap nasabah, loyalitas nasabah. 


\section{PENDAHULUAN \\ Latar Belakang}

Bank Muamalat Indonesia adalah Bank umum pertama di Indonesia yang menerapkan prinsip syariah Islam dalam menjalankan operasionalnya. Didirikan pada tanggal 1 november 1991 yang diprakarsai oleh Majelis Ulama Indonesia (MUI). Penggunaan produk pendanaan pertama kali yaitu menggunakan prinsip wadiah (titipan) dan Mudharobah (bagi hasil). Sedangkan dalam penanaman dananya menggunakan prinsip jual beli, bagi hasil, dan sewa. Bank muamalat pernah menorehkan prestasi dengan menempati posisi jawara dari hasil survei "Satisfaction, Loyalty, and Engagement (SLE) 2019" yang diselenggarakan oleh Marketing Research Indonesia (MRI) bekerja sama dengan Infobank. Survei SLE 2019 ini merupakan pengukuran kepuasan pelanggan yang tidak hanya fokus pada aspek kepuasan, tapi juga secara utuh pada satisfaction, loyalty, dan engagement secara keseluruhan dengan tujuan untuk mengukur tingkat keterikatan (engagement) nasabah terhadap bank serta faktor-faktor yang mempengaruhi hal tersebut, sedangkan kategori Bank Umum Syariah terdapat 4 Bank yang diikutsertakan dalam survei yakni: Bank Muamalat, Bank Syariah Mandiri, BRI Syariah, dan BNI Syariah.

Selain CSR, kualitas pelayanan pada bank syariah juga berpengaruh terhadap sikap nasabah dan perkembangan loyalitas nasabah karena nasabah akan mendapatkan kenyamanan dan mendapat kepuasan dalam pelayanan yang dihadirkan oleh bank atau perusahaan tersebut. Kualitas pelayanan merupakan salah satu faktor yang selama ini mempengaruhi kepuasan konsumen/nasabah secara umum, dan menjadi faktor utama dalam kepuasan konsumen atau nasabah di sebuah perusahaan jasa. Peningkatan kualitas pelayanan sebagai salah satu motivator pengikat loyalitas konsumen yang merupakan inti dari usaha di bidang jasa termasuk di dalamnya dunia perbankan. Penelitian ini replikasi dari beberapa penelitian sebelumnya yaitu penelitian dari Rahmi (2017) yang berjudul "Implementasi CSR dan citra perusahaan berpengaruh terhadap loyalitas nasabah melalui sikap nasabah pada perbankan syariah yang hasilnya CSR berpengaruh langsung terhadap sikap dan loyalitas nasabah baik secara langsung maupun melalui sikap nasabah begitupun citra perusahaan. Mukaffi (2016) menyatakan bahwa kualitas pelayanan berpengaruh terhadap kepuasan nasabah. Fanani (2018) juga menyatakan bahwa pelayanan Jasa berpengaruh signifikan terhadap kepuasan nasabah. Samsiyah (2013) menyatakan bahwa Implementasi corporate social responsibility yang dilakukan BPRS bhakti sumekar cabang pamekasan sudah sesuai dengan shariah enterprise theory.

\section{LANDASAN TEORI}

\section{Teori Stakeholder}

Premis dasar dari teori stakeholder adalah bahwa semakin kuat hubungan korporasi, maka akan semakin baik bisnis korporasi. Sebaliknya, semakin buruk hubungan korporasi maka akan semakin sulit. Hubungan yang kuat dengan para pemangku kepentingan adalah berdasarkan kepercayaan, rasa hormat, dan kerjasama. Teori stakeholder adalah sebuah konsep manajemen strategis, tujuannya adalah untuk membantu korporasi memperkuat hubungan dengan kelompok-kelompok eksternal dan mengembangkan keunggulan kompetitif (Mardikanto, 2014:68).

\section{Shariah Enterprise Theory}

Merupakan enterprise theory yang telah diinternalisasi dengan nilai-nilai Islam guna menghasilkan teori yang transendental dan lebih humanis. Enterprise theory, seperti telah dibahas oleh Triyuwono (2007:4), merupakan teori yang mengakui adanya 
pertanggungjawaban tidak hanya kepada pemilik perusahaan saja melainkan kepada kelompok stakeholders yang lebih luas. Enterprise theory mampu mewadahi kemajemukan masyarakat (stakeholders), hal yang tidak mampu dilakukan oleh proprietary theory dan entity theory.

Corporate Social Responsibility

Menurut Williams dan Siegel (2001), dalam Mursitama (2011:23) mendefinisikan CSR adalah serangkaian tindakan perusahaan yang muncul untuk meningkatkan produk sosialnya, memperluas jangkauan melebihi kepentingan ekonomi eksplisit perusahaan, dengan pertimbangan tindakan semacam ini tidak disyaratkan oleh peraturan hukum serta lingkungan hidup/bumi (planet), dan peningkatan kualitas perusahaan (profit). Menurut Carroll (1997) dalam Rudito dan Famiola (2013:64) menjelaskan komponen-komponen tanggung jawab sosial perusahaan ke dalam empat kategori, yaitu economic responsibility, ethical responsibilies, legal responsibilies, dan discretionary responsibilities.

\section{Kualitas pelayanan}

Kualitas Pelayanan merupakan bentuk pemenuhan hal-hal yang diharapkan pelanggan atas kebutuhan mereka (mukaffi, 2016). Menurut Parasuraman (1988) dalam lupyoadi dan hamdani (2006:182) yang melibatkan 800 pelanggan, disimpulkan bahwa terdapat lima dimensi , diantaranya; Berwujud (Tangibles), Reliabilitas (Reliability), Ketanggapan (Responsibility), Jaminan dan Kepastian (Assurances) dan Empati (Emphaty)

\section{Sikap nasabah}

Tiap sikap mempunyai tiga aspek yaitu (Ahmadi, 2002:162): 1. Aspek Kognitif Yaitu yang berhubungan dengan gejala mengenal fikiran. Ini berarti berwujud pengolahan, pengalaman dan keyakinan serta harapan-harapan individu tentang objek atau kelompok objek tertentu. 2. Aspek Afektik Berwujud proses yang menyangkut perasaan tertentu seperti ketakutan, kedengkian, simpati antipati dansebagainya yang ditujukan kepada objek-objek tertentu. Aspek Konatif Berwujud proses tendensi/kecenderungan untuk berbuat sesuatu objek. Dari ketiga aspek tersebut bahwa sikap mengarah pada suatu olah rasa yang yang berpengaruh secara sensitif terhadap suatu objek.

\section{Loyalitas Nasabah}

Menurut Aaker dalam Mouren Margaretha, (2004:297-298), berpendapat bahwa loyalitas sebagai suatu perilaku yang diharapkan atas suatu produk atau layanan yang antara lain meliputi kemungkinan pembelian lebih lanjut atau perubahan perjanjian layanan, atau sebaliknya seberapa besar kemungkinan pelanggan akan beralih kepada pemilik merek lain atau penyedia layanan lain.

\section{Hipotesis}

\section{Pengaruh CSR terhadap Sikap Nasabah}

Menurut teori stakeholder mengatakan bahwa perusahaan bukanlah entitas yang hanya beroperasi untuk kepentingannya sendiri namun harus memberikan manfaat bagi stakeholder-nya. (handoko, 2014-74) dan juga menurut shariah enterprise teori bahwa kesejahteraan tidak hanya diperuntukkan bagi pemilik modal, melainkan bagi kepentingan semua stakeholder (manusia). Yang artinya dengan adanya CSR perusahaan maka nasabah yang merupakan bagian dari stakeholder nantinya akan mendapatkan manfaat dari CSR tersebut sehingga dapat mempengaruhi sikap nasabah yang merasakannya. Menurut Syarifa Rahmi (2017) menyatakan bahwa CSR berpengaruh 
terhadap sikap nasabah dengan nilai signifikan sebesar 0,273. Peneletian ini juga didukung oleh hasil penelitian yang dilakukan oleh Faiqotuz Zahroh 2018 bahwa Corporate Social Responsibility (X) berpengaruh positif terhadap Keputusan Pembelian (Y2) karena memiliki nilai probalitas $(0,003)<0,05$ yang berarti ada pengaruh yang signifikan. Sehingga hipotesis yang diajukan adalah;

\section{H1 : pengaruh CSR terhadap Sikap Nasabah}

\section{Pengaruh Kualitas Pelayanan Terhadap Sikap Nasabah}

Teori stakeholder mengatakan bahwa perusahaan bukanlah entitas yang hanya beroperasi untuk kepentingannya sendiri namun harus memberikan manfaat bagi stakeholdernya. Hal ini juga sejalan dengan shariah enterprise theori bahwa kesejahteraan tidak hanya diperuntukkan bagi pemilik modal, melainkan bagi kepentingan semua stakeholder (manusia) dan juga menurut Shariah Enterprise Theori juga mencakup nilainilai syariah (keadilan, rahmatan lil alamin, dan maslahah). Djunaedi (2016) Kualitas Produk berpengaruh positif signifikan terhadap Keputusan Menabung. Penelitian ini juga didukung oleh Muhammad Cahyani, 2015 pada hasil penelitiannya bahwa Kualitas Pelayanan (X1) dan Perilaku Konsumen (X2) berpengaruh signifikan terhadap Kepuasan Konsumen (Y) Pada Jasa Outsourcing PT. Swabinagatra - Gresik. Sehingga hipotesis yang diajukan adalah :

\section{H2: Kualitas Pelayanan berpengaruh terhadap Sikap Nasabah}

\section{Pengaruh Corporate social resonsibility (CSR) Terhadap Loyalitas Nasabah.}

Shariah Enterprise Theory mencakup nilai-nilai syariah (keadilan, rahmatan lil alamin, dan maslahah) dan menurut teori stakeholder bahwa hubungan yang kuat dengan para pemangku kepentingan adalah berdasarkan kepercayaan, rasa hormat, dan kerjasama (Mardikanto, 2014:68). Yoasti, 2016 menyatakan implementasi program CSR memiliki pengaruh positif dan signifikan terhadap loyalitas konsumen sebagai salah satu ukuran Balanced Scorecard. Penelitian ini didukung oleh Rahmi 2017 yang menyatakan bahwa terdapat pengaruh langsung antara variabel CSR terhadap loyalitas nasabah sebesar 0,330. Sehingga hipotesis yang diajukan adalah :

\section{H3: CSR berpengaruh terhadapLoyalitas Nasabah}

\section{Pengaruh Kualitas Pelayanan Terhadap Loyalitas Nasabah}

Menurut Shariah Enterprise Theory menyatakan bahwa kesejahteraan tidak hanya diperuntukkan bagi pemilik modal, melainkan bagi kepentingan semua stakeholder (manusia). Artinya jika perusahaan memberikan manfaat berupa pelayanan yang baik kepada nasabah maupun calon nasabah akan menciptakan tingkat kepercayaan dan loyalitas terhadap perusahaan. Djunaidi, 2016 menyatakan bahwa Kualitas Produk berpengaruh positif signifikan terhadap Keputusan Menabung nasabah. Penelitian ini didukung oleh mukaffi (2016) yang menyatakan variabel kualitas pelayanan berpengaruh signifikan terhadap kepuasan pelanggan. Sehingga hipotesis yang diajukan adalah :

H4 : Kualitas Pelayanan Berpengaruh terhadap Loyalitas Nasabah.

\section{CSR berpengaruh terhadap Loyalitas Nasabah Melalui Sikap Nasabah}

Shariah Enterprise Theory menyatakan bahwa salah satu dari stakeholdernya adalah manusia. Manusia dalam hal ini dibedakan dalam dua kelompok, yaitu directstakeholders dan indirect-stakeholders. Menurut Rahmi (2017), bahwa CSR berpengaruh terhadap loyalitas nasabah melalui sikap nasabah. Sehingga hipotesis ke 5a adalah : 


\section{H5a: CSR berpengaruh terhadap Loyalitas Nasabah Melalui Sikap Nasabah.}

Pengaruh Kualitas Pelayanan Terhadap Loyalitas Nasabah Melalui Sikap Nasabah Menurut teori stakeholder menyatakan bahwa kesuksesan dan hidup matinya suatu perusahaan sangat tergantung pada kemampuannya menyeimbangkan beragam kepentingan dari para stakeholder atau pemangku kepentingan. Penelitian ini sejalan dengan penelitian yang dilakukan oleh mukaffi (2016) yang menyatakan secara simultan variabel Tangibles, Reliabilitas, Daya Tanggap, ]aminan, dan Empati secara simultan berpengaruh terhadap Kepuasan nasabah. Sehingga hipotesis ke 5b adalah;

H5b : Kualitas Pelayanan berpengaruh terhadap Loyalitas nasabah melalui Sikap nasabah.

\section{Kerangka Berpikir}

Gambar 1.

Kerangka Pemikiran

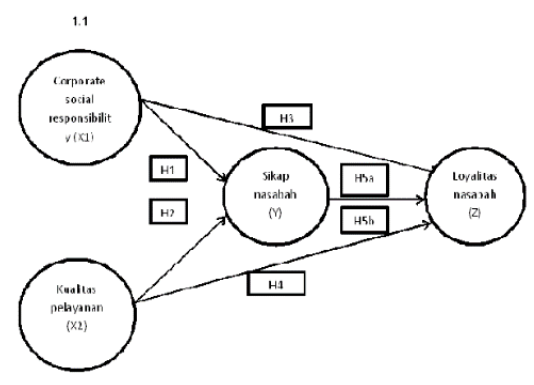

\section{METODE PENELITIAN}

\section{Populasi dan Sampel}

Populasi dalam penelitian ini yaitu Bank Muamalat KC.Malang. sedangkan sampel dalam penelitian ini adalah nasabah yang pernah merasakan atau mengetahui adanya program CSR pada bank Muamalat KC. Malang. Teknik pengambilan sampel dilakukan melalui teknik sampling Non propabilitas berdasarkan kemudahan. Elemen populasi yang dipilih sebagai subjek sampel adalah tidak terbatas sehingga peneliti memiliki kebebasan untuk memilih sampel yang paling cepat dan murah (Indriantoro 2009,130).

\section{Definisi Operasional Variabel}

Variabel Independen

Corporate Social Responsibility

Corporate Social Responsibility merupakan suatu tanggungjawab sosial perusahaan kepada masyarakat sekitar. Pengukuran skor variabel ini menggunakan skala likert berdimensi empat dengan rentang nilai 1 sampai 5 yaitu : sangat setuju (skor 5), setuju (skor 4), Netral (skor 3), tidak setuju (skor 2), sangat tidak setuju (skor 1). Berikut model indikator konstruk CSR yaitu : 
Gambar 2.

Model Indikator

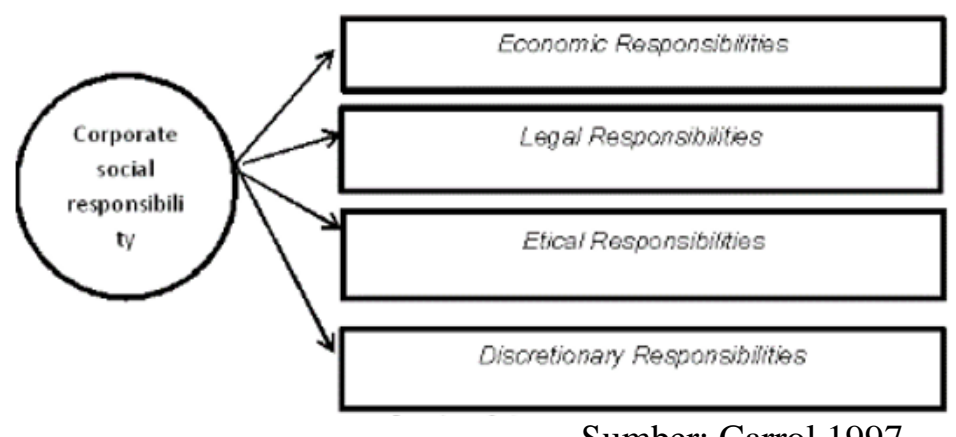

Sumber; Carrol 1997

\section{Kualitas Pelayanan}

Kualitas pelayanan merupakan tingkat kenyaman layanan yang didapat oleh pelanggan maupun nasabah untuk memberikan kepuasan kepada pelanggan agar nasabah ataupun pelanggan merasa nyaman kepada perusahaan. Pengukuran skor variabel ini menggunakan skala likert berdimensi 6 dengan rentang nilai 1 sampai 5 yaitu : sangat setuju (skor 5), setuju (skor 4), Netral (skor 3), tidak setuju (skor 2), sangat tidak setuju (skor 1). Berikut model konstruk Kualitas Pelayanan, yaitu :

Gambar 3.

Model Konstruk Kualitas Pelayanan

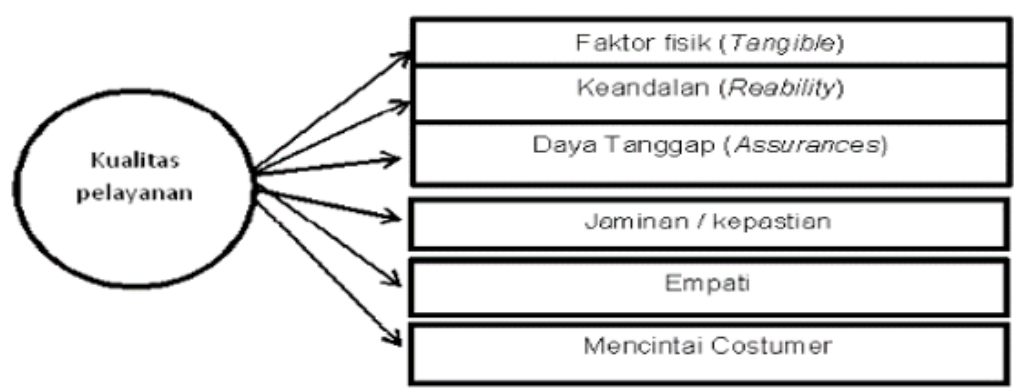

Sumber; Fanani 2018

\section{Variabel Dependen}

\section{Loyalitas Nasabah}

Loyalitas Nasabah Merupakan Tingkat Kepercayaan Nasabah terhadap suatu perusahaan. Pengukuran skor variabel ini menggunakan skala likert berdimensi empat dengan rentang nilai 1 sampai 5 yaitu : sangat setuju (skor 5), setuju (skor 4), Netral (skor 3), tidak setuju (skor 2), sangat tidak setuju (skor 1). Berikut model indikator konstruk Loyalitas Nasabah, yaitu: 
Gambar 4

Model Konstruk Loyalitas Nasabah

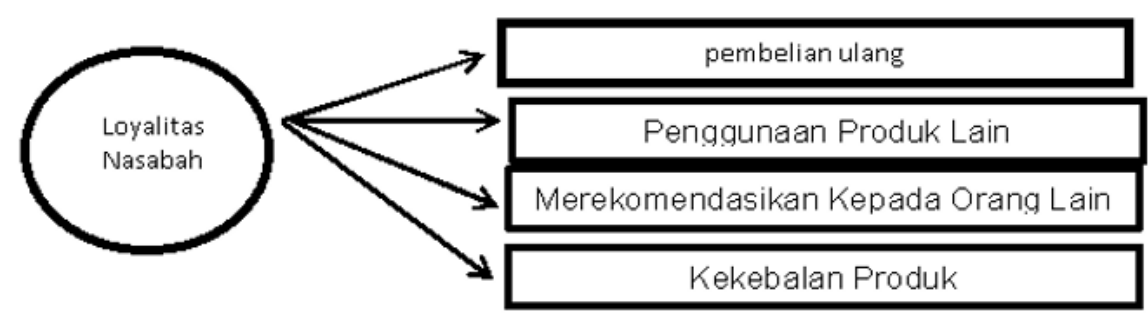

Sumber; Jill Griffin, 2007

\section{Variabel Intervening}

Adalah tipe variabel-variabel yang mempengaruhi hubungan antara variabelvariabel independen dengan variabel-variabel dependen menjadi hubungan tidak langsung. Variabel Intervening dalam penelitian ini adalah Sikap Nasabah (Y).

\section{Sikap Nasabah}

Sikap Nasabah merupakan perwakilan, atau kesukaan seseorang menyangkut suatu objek atau ide tertentu. Pengukuran skor variabel ini menggunakan skala likert berdimensi Tiga dengan rentang nilai 1 sampai 5 yaitu : sangat setuju (skor 5), setuju (skor 4), Netral (skor 3), tidak setuju (skor 2), sangat tidak setuju (skor 1). Berikut model indikator konstruk Sikap Nasabah, yaitu :

Gambar 5

Konstruk Sikap Nasabah

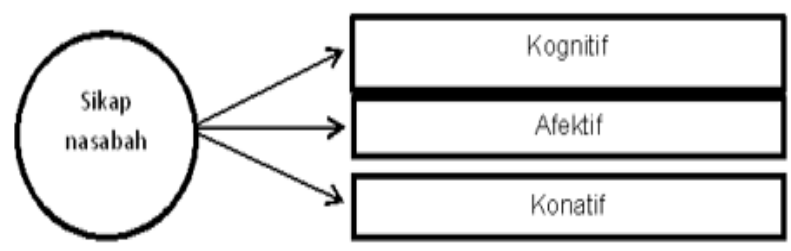

Sumber; Kanuk, 2004

\section{Teknik Analisis Data}

Teknik analisis yang digunakan dalam penelitian ini adalah SEM (Stuctural Equation Modeling), Partial Least Squares (PLS) merupakan metode analisis yang powerfull dan sering disebut juga sebagai soft modeling karena meniadakan asumsiasumsi OLS (Ordinary Least Squares) regresi, seperti data harus terdistribusi normal secara multivariate dan tidak adanya problem multikolonieritas antara variabel eksogen (Word, 1985 dalam Latan dan Gozali, 2014, 5 ).

\section{Outer Model atau Measurement Model (Model Pengukuran)}

Outer model adalah tahap analisis PLS yang dapat menilai validitas dan reabilitas konstruk penelitian. Uji validitas konstruk dilakukan untuk mengukur tingkat kemampuan instrumen penelitian terhadap pengukuran variabelnya (Jogiyanto dan 
Abdillah, 2009 dalam Irena 2019). Menurut Ghozali dan latan (2014) jika konstruk berbentuk reflektif maka evaluasi yang dilakukan untuk Outer model dilakukan dengan mengetahui nilai AVE, Cronbachs Alpha, dan nilai Composite Reliabelity. Uji reliabilitas dilakukan untuk mengukur tingkat konsistensi pada alat ukur dan konsistensi responden dalam menjawab kuisioner. Dalam uji reliabilitas menggunakan dua metode yaitu Cronbach's alpha dan Composite reliability (Jogiyanto dan Abdillah, 2009 dalam Irena 2019). Cronbach's alpha dapat mengukur batas bawah reliabilitas dari suatu konstruk penelitian. Composite reliability mengukur nilai sesungguhnya reabilitas suatu kontruk (Jogiyanto dan Abdillah, 2009 dalam Irena 2019). Outer model dapat dilakukan dengan menggunakan literasi algoritma.

\section{Inner Model atau Structural Model (Model Struktural)}

Inner model dievaluasi dengan menggunakan R2 untuk konstruk endogen. Perubahan nilai R-Squares digunakan untuk menjelaskan pengaruh variabel eksogen terhadap variabel endogen (Ghozali dan Latan, 2014). Inner model menggambarkan tingkat signifikan dalam melakukan uji hipotesis penelitian. Inner model menggambarkan tingkat signifikan dalam melakukan uji hipotesis penelitian. Apabila diperoleh nilai ( $\mathrm{p}$ value $<0,05)$ maka bisa disimpulkan signifikan begitu pula sebaliknya.

\section{PEMBAHASAN}

\section{Responden berdasarkan pengetahuan berdasarkan Corporate Social Responsibility} (CSR) Perusahaan

Apabila dilihat dari pengetahuan terhadap CSR perusahaan maka lebih dari 50\% responden merupakan Nasabah yang sekedar mengetahui program CSR, dan sisanya merupakan penerima program CSR langsung dari perusahaan. Hal ini juga terkendala oleh sulitnya peneliti menemukan karakteristik Nasabah yang terlibat langsung atau yang merasakan.

\section{Outer Loading}

Tabel 1

Hasil Uji Validitas

\begin{tabular}{|l|c|}
\hline \multicolumn{1}{|c|}{ Variabel } & Rata-rata Varians Diekstrak (AVE) \\
\hline Csr (x1) & 0,500 \\
\hline Kualitas pelayan (x2) & 0,535 \\
\hline Sikap nasabah (y) & 0,715 \\
\hline Loyalitas nasabah (z) & 0,734 \\
\hline
\end{tabular}

Dari hasil outer loading di atas menunjukkan semua data valid dan memenuhi nilai descriminan validity yaitu Ave $>0,50$.

\section{Cronbach's Alpha atau uji reliabilitas}

Pengujian selanjutnya adalah reliability konstruk dengan melihat output cronchbach's alpha dan composite relibility. Reliabilitas bertujuan untuk mengukur konsistensi alat ukur dan menunjukkan akurasi, konsistensi, dan ketepatan suatu alat ukur dalam melakukan pengukuran (Jogiyanto \& Abdillah, 2009:61 dalam Irena 2019). Kriteria dikatakan reliabel apabila nilai cronchbach's alpha dan composite relibility lebih 
dari 0,7 (Ghozali dan Latan, 2014). Hasil dari cronchbach's alpha dan composite relibility dapat dilihat pada tabel 2 :

Tabel 2.

Cronbach's Alpha \& Realibility Composite

\begin{tabular}{|c|c|c|}
\hline Variabel & Cronbach's Alpha & Reliability composite \\
\hline (X1) & 0,939 & 0,945 \\
\hline (X2) & 0,936 & 0,944 \\
\hline (Y) & 0,920 & 0,938 \\
\hline (Z) & 0,938 & 0,950 \\
\hline
\end{tabular}

Sumber: Data diolah

Berdasarkan Tabel tersebut di atas menunjukkan bahwa semua variabel penelitian sudah menunjukkan sebagai pengukur yang fit. Hal tersebut dapat diartikan bahwa semua item pertanyaan yang digunakan untuk mengukur masing-masing variabel adalah reliabel.

\section{Pengaruh CSR terhadap Sikap Nasabah}

Berdasarkan hasil penelitian diketahui bahwa Corporate Social Responsibility tidak berpengaruh secara signifikan terhadap Sikap Nasabah. Hal ini dapat dilihat dari nilai p-value sebesar 0,424 yang berarti lebih besar dari 0,05. Dengan demikian hipotesis pertama "Corporate Social Responsibility berpengaruh terhadap Sikap Nasabah", dapat dinyatakan tidak diterima. Penelitian ini tidak sejalan Rahmi (2017) tentang pengaruh implementasi CSR terhadap loyalitas nasabah dan sikap nasabah sebagai variabel intervening menyatakan bahwa CSR berpengaruh signifikan terhadap Sikap Nasabah. berdasarkan teori stakeholder bahwa perusahaan bukanlah entitas yang hanya beroperasi untuk kepentingannya sendiri namun harus memberikan manfaat bagi stakeholder-nya. juga menurut shariah enterprise theori bahwa kesejahteraan tidak hanya diperuntukkan bagi pemilik modal, melainkan bagi kepentingan semua stakeholder (manusia).

\section{Kualitas Pelayanan terhadap Sikap Nasabah}

Berdasarkan hasil penelitian diketahui Kualitas Pelayanan berpengaruh langsung signifikan terhadap Sikap Nasabah. Hal ini dapat dilihat dari nilai p-value sebesar 0,000 yang berarti lebih kecil dari 0,05 dengan demikian Hipotesis kedua "Kualitas Pelayanan berpengaruh terhadap Sikap Nasabah" dapat dinyatakan diterima. Penelitian ini sejalan dengan teori sikap nasabah menurut Sumarwan (2003:154) menjelaskan bahwa sikap (attitudes) nasabah adalah faktor penting yang akan mempengaruhi keputusan nasabah. Konsep sikap sangat terkait dengan kepercayaan dan perilaku. Penelitian ini sejalan dengan penelitian yang dilakukan oleh Djunaedi (2016) Kualitas Produk berpengaruh positif signifikan terhadap Keputusan Menabung. Penelitian ini juga didukung oleh Muhammad Cahyani, 2015 pada hasil penelitiannya bahwa Kualitas Pelayanan (X1) dan Perilaku Konsumen (X2) berpengaruh signifikan terhadap Kepuasan Konsumen (Y). Hal ini juga sejalan dengan teori stakeholder dan Shariah Enterprise Theory yang menyatakan bahwa perusahaan bukanlah entitas yang hanya beroperasi untuk kepentingannya sendiri namun harus memberikan manfaat bagi stakeholdernya dan kemaslahatan masyrakat bersama. 


\section{Pengaruh CSR Terhadap Loyalitas Nasabah}

Berdasarkan hasil penelitian diketahui CSR berpengaruh langsung signifikan terhadap Loyalitas Nasabah. Hal ini dapat dilihat dari nilai p-value sebesar 0,020 yang berarti lebih kecil dari 0,05 dengan demikian hipotesis kedua "CSR berpengaruh terhadap Loyalitas Nasabah", dapat dinyatakan diterima. Penelitian ini sejalan dengan Yoasti, 2016 yang menyatakan implementasi program CSR memiliki pengaruh positif dan signifikan terhadap loyalitas konsumen sebagai salah satu ukuran Balanced Scorecard. Penelitian ini didukung oleh Rahmi 2017 yang menyatakan bahwa terdapat pengaruh langsung antara variabel CSR terhadap loyalitas nasabah, dan juga sejalan dengan Teori stakeholder yang menyatakan Hubungan yang kuat dengan para pemangku kepentingan adalah berdasarkan kepercayaan, rasa hormat, dan kerjasama.

\section{Pengaruh Kualitas Pelayanan terhadap Loyalitas Nasabah}

Berdasarkan hasil penelitian diketahui Kualitas Pelayanan tidak berpengaruh langsung signifikan terhadap Loyalitas Nasabah. Hal ini dapat dilihat dari nilai p-value sebesar 0,225 yang berarti lebih besar dari 0,05 dengan demikian hipotesis keempat "Kualitas Pelayanan berpengaruh terhadap Loyalitas Nasabah" dapat dinyatakan tidak dapat diterima. Penelitian ini tidak sejalan dengan penelitian yang Djunaidi (2016) menyatakan bahwa Kualitas Produk berpengaruh positif signifikan terhadap Keputusan Menabung nasabah. Alasan hipotesis tertolak yakni adanya ketidaksesuaian data responden dengan harapan peneliti terhadap responden yang terdapat pada tabel 4.1 menyataakan bahwa responden sebanyak $47 \%$ merupakan nasabah baru yang belum sampai jangka waktu satu tahun dan sisanya merupakan nasabah lama sedangkan harapan dari peneliti adalah responden yang sudah lama menjadi Nasabah dengan harapan responden yang lebih lama menjadi Nasabah di suatu Perbankan akan lebih bisa menilai Kualitas Pelayanan dari perusahaan yang berdampak pada tingkat Loyalitas Nasabah.

\section{Pengaruh CSR dan Kualitas Pelayanan Terhadap Loyalitas Nasabah Melalui Sikap nasabah}

a) Pengaruh CSR terhadap Loyalitas Nasabah Melalui Sikap Nasabah

Berdasarkan hasil penelitian diketahui Corporate Responsibility tidak berpengaruh signifikan terhadap Loyalitas Nasabah melalui Sikap Nasabah. Hal ini dilihat dari nilai p-value sebesar 0,434 yang berarti lebih besar dari 0,05 dengan demikian hipotesis lima B "CSR terhadap Loyalitas Nasabah Melalui Sikap Nasabah" dapat dinyatakan ditolak. Penelitian Ini tidak sejalan dengan penelitian yang dilakukan oleh Rahmi (2017) yang menyatakan CSR berpengaruh signifikan positif secara tidak langsung melalui sikap nasabah. Menurut teori stakeholder bahwa kesuksesan dan hidup matinya suatu perusahaan sangat tergantung pada kemampuannya menyeimbangkan beragam kepentingan dari para stakeholder atau pemangku kepentingan, dan juga menurut Shariah Enterprise Theory bah stakeholder bahwa stakeholder yang dimaksud tidak hanya manusia yang memiliki keterlibatan langsung dengan perusahaan, masyaraat setempat yang tidak punya keterlibatan langsung dengan perusahaan seperti masyarakat diluar perusahaan juga memiliki hak kesejahteraan dari perusahaan.

\section{b) Pengaruh CSR dan Kualitas Pelayanan Terhadap Loyalitas Nasabah Melalui Sikap nasabah}

Sedangkan Kualitas Pelayanan berpengaruh terhadap Loyalitas Pelayanan melalui Sikap Nasabah. Hal ini dilihat dari nilai p-value sebesar 0,000 yang berarti lebih kecil 
dari 0,05 dengan demikian hipotesis lima B "Kualitas Pelayanan terhadap Loyalitas Nasabah melalui Sikap Nasabah" dapat dinyatakan diterima. penelitian ini sejalan dengan penelitian yang dilakukan oleh mukaffi (2016) menyatakan Secara simultan variabel Tangibles, Reliabilitas, Daya Tanggap, ]aminan, dan Empati secara simultan (bersamasama)(variabel dari kualitas pelayanan) berpengaruh terhadap Kepuasan nasabah. menurut teori stakeholder bahwa kesuksesan dan hidup matinya suatu perusahaan sangat tergantung pada kemampuannya menyeimbangkan beragam kepentingan dari para stakeholder atau pemangku kepentingan. juga menurut Shariah Enterprise Theory bahwa stakeholder yang dimaksud tidak hanya manusia yang memiliki keterlibatan langsung dengan perusahaan, masyaraat setempat yang tidak punya keterlibatan langsung dengan perusahaan seperti masyarakat diluar perusahaan juga memiliki hak kesejahteraan dari perusahaan. Yang artinya hasil dari penelitian ini dengan adanya peningkatan kualitas pelayanan yang baik terhadap stakeholder (dalam hal ini adalah nasabah) dan juga bukan nasabah mampu memberikan pengaruh terhadap loyalitas nasabah melalui sikap nasabah.

Tabel 3.

R Square \& Adjusted R Square

\begin{tabular}{|c|c|c|}
\hline & R Square & Adjusted R Square \\
\hline$(Y)$ & 0,516 & 0,506 \\
\hline$(Z)$ & 0,608 & 0,595 \\
\hline
\end{tabular}

Sumber : Data yang diolah

Dari data hasil Inner Model di atas menunjukkan bahwa hasil nilai $R$ SQUARE yang dipakai adalah Ajusted Square karena data yang digunakan berupa sampel. Dari hasil penelitian menunjukkan bahwa penelitian ini yang mempengaruhi variabel Sikap nasabah (Y) sebesar 0,506 atau 50.6\% dan sisanya dapat dipengaruhi oleh variabel lain, yang kedua yaitu Variabel loyalitas Nasabah dengan nilai 0.595 atau sebesar 59,5\% artinya dipenelitian ini mampu mempengaruhi variabel Loyalitas Nasabah sebesar 59,5 $\%$ dan sisanya dapat dijelaskan oleh variabel lain diluar penelitian ini.

\section{SIMPULAN DAN SARAN}

CSR berpengaruh terhadap loyalitas nasabah tanpa melalui sikap nasabah yang artinya bahwa dengan adanya implementasi CSR dari Bank Muamalat KC. Malang dapat menjadikan nasabah yang mengetahui ataupun pernah merasakan akan loyal terhadap perusahaan tanpa adanya mediasi diantaranya. Sedangkan dengan adanya kualitas pelayanan yang baik akan mampu membuat nasabah loyal dengan catatan nasabah merasakan secara langsung implementasi atau dampak yang di hasilkan melalui sikap nasabah. Dengan hal ini sikap nasabah sebagai variabel intervening/mediasi tidak mampu menjadi intervening bagi variabel CSR.

Bagi Bank Muamalat KC. Malang, diharapkan dapat meningkatkan kualitas CSR yang dimiliki agar lebih tepat sasaran supaya memberikan dampak positif terhadap kemajuan Bank Muamalat KC. Malang, dan juga dapat mempertahankan dan memperbaiki Kualitas Pelayanan yang selama ini memiliki dampak positif terhadap Sikap dan Loyalitas Nasabahnya 


\section{DAFTAR PUSTAKA}

A.S, Moenir., 1992. Manajemen Pelayanan Umum di Indonesia. Jakarta:Bumi Aksara. Abdillah, W., \& Jogianto, H.M. (2009). Konsep dan Aplikasi PLS (Partial Least Square) Untuk Penelitian Empiris. Yogyakarta: Badan Penerbit Fakultas Ekonomi.

Adrian, Payne, (2000), Pemasaran Jasa, The Essence of Service Maerketing, Andi Yogyakarta

Arifin Z Ahmad." Pengaruh corporate social responsibility dengan cause branding dan venture philanthrophy terhadap profitabilitas bank syariah. Fakultas Ekonomi dan Bisnis Islam UIN Sunan Kalijaga Yogyakarta.

Arna Suryani dan Eva Herianti, "Pengaruh Pengungkapan Tanggung Jawab Sosial Perusahaan terhadap Koefisien Respon Laba dan Manajemen Laba" Simposium Nasional Akuntansi XVIII Universitas Sumatera Utara, Medan.

Azheri, Busyra. 2012, Corporate Social Responsibility, Jakarta: Raja Grafindo Persada.

Cahyani Muhammad. 2015." Pengaruh kualitas pelayanan dan perilaku konsumen terhadap minat pembelian ulang melalui kepuasan konsumen jasa outsourcing pt. Swabinagatra di gresik. Volume 04, Nomor 02, Desember 2015 Hal 190 - 197.

Churchill, Gilbert A. (2002). Dasar-dasar Pemasaran Edisi 4, Jilid 1. Jakarta: Erlangga. Djunaedi.2016." Pengaruh Corporate Social Responsibility (CSR), dan Kualitas Produk Terhadap, Citra Bank dan Keputusan Menabung di BNI Syariah Kota Kediri. Jurnal Ilmu Ekonomi \& Manajemen September 2016, Vol. 3 No.2. hal. 104 - 119.

Fahmi, Irham. 2015. Analisis Laporan Keuangan, Cetakan Ke-5. Bandung : Alfabeta.

Faiqotu Zzahroh \& Achmad Fauzi DH. 2018." Pengaruh corporate social responsibility (csr) terhadap citra merek dan dampaknya pada keputusan pembelian (Survei pada Pengunjung Taman Slamet Kota Malang yang Mengkonsumsi Produk Bentoel). Jurnal Administrasi Bisnis (JAB)|Vol. 57 No. 2 April 2018.

Fanani A Hafid.2018.'Pengaruh Pelayanan Jasa Terhadap Kepuasan Nasabah Pada Bank Rakyat Indonesia (Persero) TBK Malang. Fakultas Ekonomi. Universitas Islam Negeri Maulana Malik Ibrohim: Malang.

Fandy, Tjiptono. 2004. Manajemen Jasa, Edisi Pertama, Yogyakarta: Andi Offset.

Freeman, R. Edward. (1994). Strategic Management: A stakeholder Approach. Boston: Pitman.

Gerianta Wirawan Yasa, "Pemeringkatan Obligasi Perdana Sebagai Pemicu Manajemen

Ghozali Imam, Latan Hengky. 2014." Partial least squares (konsep, teknik, dan aplikasi smartpls 3.0). Semarang: Universitas Diponegoro Semarang ISBN: 979.704.300.2.

Ghozali, Imam. 2014. Structural Equation Modeling, Metode Alternatif denganPartial Least Square (PLS). Edisi 4. Semarang: Badan Penerbit Universitas Diponegoro. http://Vacancycentre.com

Indriantoro Nur, Supomo Bambang. 1999."Metodologi Penelitian Bisnis Untuk Akuntansi \& Manajemen. Yogyakarta: Fakultas Ekonomi UGM. ISBN : 979-503$372-7$.

Irena.A.N. 2019. "analisis pengaruh kompetensi aparatur, sistem pengendalian internal dan moralitas individu terhadap kecenderungan kecurangan (fraud) (Studi Pada Pengelola Dana Desa)”. Fakultas Ekonomi dan Bisnis , Universitas Trunojoyo Madura : Bangkalan.

Kanuk, L.c. (2007). Perilaku Konsumen. Yogyakarta: PT. Indeks.

Kartajaya, Hermawan dan Muhammda Syakir Sula, 2006. Syariah Marketing. Bandung: PT. Mizan Pustaka. 
Kasmir. 2010. Pemasaran Bank. Jakarta: Prenada Media.

Kotler, philip dan Kevin Lanne Keller. 2008. Manajemen Pemasaran, Jakarta: penerbit Erlangga.

Laba: Bukti Empiris dari Pasar Modal Indonesia”, Simposium Nasional Akuntansi XIII. Purwokerto, 2010

Malangtoday.NET

Margaretha, Mouren. 2004. "Studi mengenai loyalitas pelanggan pada divisi asuransi kumpulan AJP bumi Putra”. Jurnal Sains Pemasaran Indonesia,Vol. iii, No. 3, halaman 294-298.

Marzully Nur dan Denies Priantinah, "Analisis Faktor-Fakor yang Mempengaruhi Pengungkapan Corporate Social Responsibility" Jurnal Nominal, Vol I, No I, 2012.

Muhamad Turmudi. 2018." Pemanfaatan Dana Corporate Social Responsibility Bank Syariah Mandiri Cabang Kendari. Fakultas Ekonomi dan Bisnis Islam Institut Agama Islam Negeri Kendari, Indonesia. Al Izzah: Jurnal Hasil-Hasil PenelitianISSN: 1978-9726 (p); 2541-0717 (e) Volume 13, Nomor 1 (Mei, 2018).

Mukaffi Zaim. 2016." Pengaruh Kualitas Pelayanan Perbankan Syariah TerhadaP KePuasan Nasabah. El-Dinar, Vol. 4, No. 2, Juli 2016.

Mursitama, Tirta, dkk. 2011, Corporate Social Responsibility di Indonesia (Teori dan Implementasi). Institute for Development Of Economic and Finance (INDEF).

Ni'am F Muhammad.2017."Analisis Pengaruh Kualitas Layanan Perbankan Terhadap Kepuasan Nasabah(Studi Pada Nasabah PT.Bank Negara Indonesia (Persero) Tbk Cabang Mojosari Mojokerto). Jurusan Manajemen. Fakultas Ekonomi. Universitas Islam Negeri Maulana Malik Ibrohim: Malang.

Nifita, Ade T. (2010), Pengaruh Citra BCA Terhadap Loyalitas Nasabah Tabungan BCA Cabang Jambi Vol.2 NO.2 (158-169).

Rahmi,S. 2017. "Pengaruh Implementasi Corporate Social Responsibility dan Citra Perusahaan Terhadap Loyalitas Nasabah dan Sikap nasabah Sebagai Variabel Intervening(Studi Kasus Nasabah Penerima Program CSR Bank Nagari Syariah Cabang Padang).Fakultas Ekonomi dan Bisnis. Universitas Islam Negeri Syarif Hidayatullah: Jakarta.

Republika.co.id

Ringle, C. M., Wende, S., dan Becker, J.-M. 2015. "SmartPLS 3." Boenningstedt: SmartPLS GmbH, http://www.smartpls.com.

Rivai, Veithzal. 2012. Islamic Marketing Membangun dan Mengembangkan Bisnis dengan Praktik Marketing Rasulullah saw. Jakarta: Pt. Gramedia pustaka.

Samsiyah.,et al. 2013. Kajian Implementasi Corporate Social Responsibility Perbakan Syariah Ditinjau Dari Sharia Enterprise Theory Pada PT.Bank Pembiayaan Rakyat Syariah Bhakti Sumekar Cabang Pamekasan. Jurnal InFestasi. Vol.9 No.1: Hal 47-60.

Sugiyono. 2013. Metode Penelitian Pendidikan Pendekatan Kuantitatif, Kualitatif, dan $R \& D$. Bandung: Alfabeta.

Sumarwan, Ujang. (2003). Perilaku Konsumen: Teori dan Penerapannya Dalam Pemasaran. Jakarta: Erlangga.

surya.co.id.2018

Toriquddin, Moh. Jurnal. Etika Pemasaran Persepektif Al-quran dan relevansinya dalam perbankan syariah. UIN Malang. 
Totok Mardikanto, CSR (Corporate Social Responsibility) (Tanggung Jawab Sosial Perusahaan), Alfabeta, Bandung, 2014

Triguno (1997). Budaya Kerja Menciptakan Lingkungan Kondusif untuk Meningkatkan ProduktivitasLerja. Jakarta : Golden Terayon Press.

Triyuwono, Iwan. 2007, Mengangkat "sing liyan" untuk Formulasi Nilai Tambah Syariah. Simposium Nasional Skuntansi X Universitas Hasanuddin. Tanggal 2628 Juli 2007. Hal:1-21. Makasar.

Wibisono, Yusuf. 2007. Membedah Konsep \& Aplikasi CSR Corporate Social Responsibility. Gresik Fascho Publishing.

www.Bankmuamalat.com

Yoasti L Gama.2016." Pengaruh implementasi program corporate social responsibility terhadap loyalitas konsumen sebagai salah satu ukuran balanced scorecard pada pt. Madubaru kabupaten bantul provinsi daerah istimewa yogyakarta. Jurnal Profita Edisi 6 Tahun 2016. 